McGill Law Journal

Revue de droit de McGill

\title{
D. Rhidian Thomas, ed., Legal Issues Relating to Time \\ Charterparties (London, U.K.: Informa, 2008), pp. xi, 378
}

\section{William Tetley}

Volume 55, numéro 2, july 2010

URI : https://id.erudit.org/iderudit/045092ar

DOI : https://doi.org/10.7202/045092ar

Aller au sommaire du numéro

Éditeur(s)

McGill Law Journal / Revue de droit de McGill

ISSN

0024-9041 (imprimé)

1920-6356 (numérique)

Découvrir la revue

Citer ce compte rendu

Tetley, W. (2010). Compte rendu de [D. Rhidian Thomas, ed., Legal Issues Relating to Time Charterparties (London, U.K.: Informa, 2008), pp. xi, 378]. McGill Law Journal / Revue de droit de McGill, 55(2), 367-370.

https://doi.org/10.7202/045092ar d'utilisation que vous pouvez consulter en ligne.

https://apropos.erudit.org/fr/usagers/politique-dutilisation/ 
McGill Law Journal Revue de droit de McGill

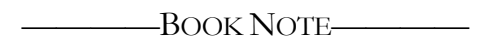

D. Rhidian Thomas, ed., Legal Issues Relating to Time Charterparties (London, U.K.: Informa, 2008), pp. xi, 378.

Two important texts on time charters under English maritime law have appeared almost simultaneously and the event immediately causes the maritime establishment (i.e., shipowners, charterers, stevedores, operators, shippers, receivers, merchants, agents, lawyers, judges etc.), and of course the academics, last but not least, (especially in our own minds) to ask, Which is the better text-i.e., the more accurate, the more practical, the more useful?

The first text, Legal Issues Relating to Time Charterparties ${ }^{1}$, is reviewed here. The second text is the compendious sixth edition of Time Charters $^{2}$. The short answer to the question Which is the better text? is that each fulfills a useful, necessary, and different purpose, so that the texts complement each other and their sum standing together is far greater than their sum standing alone.

Legal Issues consists of sixteen essays by sixteen legal experts who explored particular problems relating to time charterparties at a colloquium in Swansea, Wales, on 11 and 12 July 2007. The sixth edition of Time Charters, on the other hand, is a detailed legal examination (from stem to stern) of time charterparties under English law.

The United Kingdom is fortunate to have both studies to explain its time chartering law. Similarly the world's shipping industry is fortunate to have English time charter law extended beyond the boundaries of the United Kingdom, by means of choice of law, choice of jurisdiction, and choice of arbitration clauses as elucidated by these two texts.

At this point, I leave Time Charters to its readers, wish them bon voyage et bonne lecture, and turn my attention to Legal Issues.

The stage for Legal Issues is set in a perceptive "Foreword" by Sir Anthony Evans, former Judge of the Court of Appeal and now Chief Justice of the DIFC Courts in Dubai, U.A.E. He notes how "conferences and semi-

1 D. Rhidian Thomas, Legal Issues Relating to Time Charterparties (London, U.K.: Informa, 2008) [Legal Issues].

2 Terence Coghlin et al., eds., Time Charters, 6th ed. (London, U.K.: Informa, 2008) [Time Charters]. 
nars like this colloquium ... mingle practical experience with the fruits of top-level legal thinking and research."3

Rhidian Thomas follows in a very useful "Preface", wherein he adroitly defines and explains the central importance of the time charterparty to maritime law. "[It] rarely exists in isolation," because it is the father of "sub-time and sub-voyage charterparties," and is connected to "bills of lading, waybills and delivery orders." ${ }^{4} \mathrm{He}$ adds, "In turn, it may itself be created under a bareboat (demise) charterparty." "Thereafter, the sixteen experts (including Thomas) present the special topic of their expertise.

Time and space do not permit a detailed discussion of the sixteen essays, but a convincing explanation can be made of how essays in general contribute very beneficially to the understanding of the law of charterparties as presented in a single, detailed, and all-inclusive book such as Legal Issues.

A major advantage of a collection of essays is that each essayist chooses the subject of which he is an expert, and then allows himself free rein to cover the issues carefully. Thus we find Grant Hunter, the acknowledged authority on BIMCO forms, conducting a comparison of the three major BIMCO charterparties: BALTIME 1939 (as revised in 2001), NYPE 93, and GENTIME. ${ }^{6}$

Other essayists ask a question as their main theme, and then answer it. For example, see Dr. Baris Soyer's essay, "Constructing Terms in Time Charterparties - Beginning of a New Era or Business as Usual?" 7 Or see Andrew Tettenborn's chapter, "Assignees of Hire: How Far Can They Ignore Charterers' Claims Against Owners?" Or see Richard Williams, who cuts quickly to the bone and addresses the question "What is a Lien?"-a subject not everyone can agree upon. A most provocative question is posed by Mark Hamsher, who asks, Is the approach of the judges in Hongkong Fir still valid today?8 Or see David Foxton's essay "Indemnities in Time Charters"9 in which he skilfully leads his witness (the reader) to the an-

Legal Issues, supra note 1 at vi.

Ibid. at vii.

5 Ibid.

6 See Grant Hunter, "Standard Forms - The BIMCO Experience" in Legal Issues, supra note 1,1 .

7 Baris Soyer, "Constructing Terms in Time Charterparties - Beginning of a New Era or Business as Usual?” in Legal Issues, supra note 1, 17.

8 Mark Hamsher, "Seaworthiness and the Hongkong Fir Decision" in Legal Issues, supra note $1,83$.

9 David Foxton, "Indemnities in Time Charters" in Legal Issues, supra note 1, 93. 
swer he is looking for, no doubt relying on his experience as a barrister conducting cross-examinations in court.

Some essayists even have the courage to present a conclusion at the end of their essays. See Howard Bennett's "Safe Port Clauses"10 or Yvonne Baatz's "Clauses Paramount in Time Charters"11, or Andrew Taylor's "Damages for Breach of Time Charter: Some Recent Developments", where the author concludes that awarding damages in each time charterparty case is very subjective, being "based on what the court considers to be fair" in the circumstances. ${ }^{12}$

Courageous conclusions are also drawn by Theodora Nikaki in an essay about the allocation of cargo claims, ${ }^{13}$ Christopher Hancock in his chapter on slot charters, ${ }^{14}$ Keith Michel in his piece on war, terror, piracy, and frustration, ${ }^{15}$ and John D. Kimball in "Termination of Rights under Time Charters". ${ }^{16}$

Finally, Francis Reynolds, the unofficial Dean of English maritime law essayists, obeys his own essay rules and delivers a very selective but elegant dissertation on the subject he knows best: charterparties and bills of lading. ${ }^{17}$

The essay form thus allows the author to be discursive, bringing in history, personal experiences and even wit. There can be no excuse for an essayist being dull or ponderous and this collection of essays does not fall into that trap.

Certainly, Legal Issues establishes that reasoned essays on charterparty subjects are a valuable complement to a detailed, general text such as Time Charters. Questions, however, will no doubt be asked in the future, when a second edition of Legal Issues is planned. For example, to

10 Howard Bennett, "Safe Port Clauses" in Legal Issues, supra note 1, 47.

11 Yvonne Baatz, "Clauses Paramount in Time Charters" in Legal Issues, supra note 1, 177.

12 Andrew Taylor, "Damages for Breach of Time Charter: Some Recent Developments" in Legal Issues, supra note 1, 257 at 267.

13 Theodora Nikaki, "The Allocation of Cargo Claims between Owners and Charterers in NYPE Charterparties" in Legal Issues, supra note 1, 225.

14 Christopher Hancock, "Containerisation, Slot Charters, and the Law" in Legal Issues, supra note 1, 247.

15 Keith Michel, "War, Terror, Piracy and Frustration in a Time Charter Context" in Legal Issues, supra note 1, 199 .

16 John D. Kimball, "Termination of Rights under Time Charters" in Legal Issues, supra note 1,215 .

17 See Francis Reynolds, "Time Charterparties and Bills of Lading" in Legal Issues, supra note $1,161$. 
what degree, with the passage of time, will the contributing essayists be obliged by the editor to partially modify their views? And will any essays in the first edition have become completely redundant?

Again, to the readers of Legal Issues and, in this case, to the essayists as well, bon voyage et bonne lecture.

William Tetley C.M., Q.C.

\begin{abstract}
BOOK NOTE
R.W. Kostal, A Jurisprudence of Power: Victorian Empire and the Rule of Law (Oxford and New York: Oxford University Press, 2008), pp. xiii, 529.
\end{abstract}

First published in hardback in 2005, reprinted in 2006, and first published in paperback in 2008, R.W. Kostal's A Jurisprudence of Power: Victorian Empire and the Rule of Law 18 is usefully contrasted with other recent works on the rule of law such as Brian Z. Tamanaha's On the Rule of Law: History, Politics, Theory. ${ }^{19}$ As opposed to covering thousands of years as well as the politics and theory of the rule of law in 180 pages, Kostal, a historian and professor of law at the University of Western Ontario, and author of Law and English Railway Capitalism, 1825-1875, ${ }^{20}$ spends 529 pages (comprising an introduction, seven chapters, an epilogue, a conclusion, and an appendix) focusing on one historical episode spanning less than a decade.

A Jurisprudence of Power provides an extensive treatment grounded in primary sources, including journalistic ones, of "the prolonged conflict that arose in England over the suppression of the Morant Bay uprising in Jamaica" in October 1865, when "a crowd of black men and women attacked and burned" a courthouse. ${ }^{21}$ Its suppression involved the proclamation of martial law by then Governor of Jamaica, Edward John Eyre, and the "killing and torturing [of] hundreds of black Jamaicans-that is to say, British subjects." 22 The prolonged conflict that arose in England cen-

18 R.W. Kostal, A Jurisprudence of Power: Victorian Empire and the Rule of Law (Oxford and New York: Oxford University Press, 2008) [A Jurisprudence of Power].

19 Brian Z. Tamanaha, On the Rule of Law: History, Politics, Theory (Cambridge: Cambridge University Press, 2004).

20 R.W. Kostal, Law and English Railway Capitalism, 1825-1875 (Oxford: Clarendon Press, 1994).

21 A Jurisprudence of Power, supra note 1 at 1.

22 Ibid. 